\title{
Analisis Kendala-Kendala Dalam Penerapan SMM ISO 9001:2008 di Madrasah Aliyah Negeri 3 Palembang
}

\author{
Muhammad Haikal Dhafier \\ Magister Manajemen Pendidikan Islam UIN Raden Fatah, Palembang, Indonesia \\ mhaikaldhafier@gmail.com
}

\begin{abstract}
The purpose of this study is to describe and analyze the constraints in implementing ISO 9001: 2008 QMS in MAN 3 Palembang referring to the concept of plan, do, check, action (PDCA), and its application to quality management principles, namely: 1) customer focus ( Customer Focus) through the madrasah service survey, 2) analysis of constraints in applying the ISO QMS in MAN 3 Palembang is the focus on customers which is students through a madrasa service survey which is a matter of facilities in the classroom and student toilet. The research design is descriptive using a qualitative approach with interviews, documentation studies and observations. Data obtained from respondents through interview techniques, documentation studies, and observations regarding experiences, opinions, knowledge and other aspects to be collected, reduced, presented, and drawn conclusions to have meaning. Based on the results of data analysis and discussion it can be concluded as follows: 1) the implementation of the ISO 9001: 2008 Quality Management System through madrasa service surveys and internal quality audits that lead to continuous improvement and customer satisfaction, 2) obstacles in implementation are problems of infrastructure facilities in the classroom students for example the fan is broken and the projector is dead, and infrastructure problems in the student toilet are, the toilet lights are off and the door is loose, 3) the effort to overcome these problems is to fix it immediately.
\end{abstract}

Keywords: implementation of ISO 9001: 2008, service survey, facility constraints analysis.

Abstrak. Tujuan penelitian ini adalah untuk mendiskripsikan dan menganalisis kendalakendala dalam penerapan SMM ISO 9001:2008 di MAN 3 Palembang mengacu pada konsep plan, do, check, action (PDCA), dan penerapannya pada prinsip manajemen mutu yakni : 1) fokus pada pelanggan (Customer Focus) melalui survei layanan madrasah, 2) analisis kendala dalam penerapan SMM ISO di MAN 3 Palembang adalah fokus pada pelanggan yaitu siswa melalui survei layanan madrasah yaitu masalah fasilitas di ruang kelas dan wc siswa. Rancangan penelitian adalah deskriptif menggunakan pendekatan kualitatif dengan metode wawancara, studi dokumentasi dan observasi. Data yang diperoleh dari responden melalui teknik wawancara, studi dokumentasi, dan observasi mengenai pengalaman, pendapat, pengetahuan dan aspek lainnya untuk dapat dikumpulkan, direduksi, disajikan, dan ditarik kesimpulan agar memiliki makna. Berdasarkan hasil analisis data dan pembahasan dapat disimpulkan sebagai berikut: 1) penerapan Sistem Manajemen Mutu ISO 9001:2008 melalui survei layanan madrasah dan audit mutu internal yang mengarah kepada perbaikan berkelanjutan dan kepuasan pelanggan, 2) kendala-kendala dalam penerapan adalah masalah fasilitas prasarana dikelas siswa yaitu,kipas angin yang rusak dan proyektor yang mati, dan masalah prasarana di wc siswa yaitu, lampu wc yang mati dan pintunya yang lepas, 3) upaya untuk mengatasi masalah-masalah tersebut adalah segera memperbaikinya.

Kata Kunci: penerapan sistem manajemen mutu ISO 9001:2008, survei layanan, analisis kendala fasilitas.

\section{PENDAHULUAN}

Standar ISO yang sesuai dengan penerapan di dunia pendidikan adalah ISO 9001: 2008. Dengan penerapan prinsip-prinsip Sistem Manajemen Mutu ISO 
$\overline{9001: 2008 \text { pada sekolah atau lembaga pendidikan diharapkan sekolah akan }}$ berkembang menjadi lebih baik dalam hal memenuhi kepuasan pelanggan, yaitu siswa dan orang tua siswa. Sistem Manajemen Mutu (SMM) ISO 9001:2008 harus mengarah kepada customer satisfaction (kepuasan pelanggan) yaitu fokus pencapaian kepada kepuasan pelanggan yaitu siswa dan orang tua siswa. Manajemen mutu merupakan suatu teori ilmu manajemen yang mengarahkan pimpinan organisasi dan personelnya untuk melakukan program perbaikan mutu secara berkelanjutan yang terfokus pada pencapaian kepuasan para pelanggan.

Terkait dengan mutu pendidikan, Sistem Manajemen Mutu (SMM) ISO 9001:2008 merupakan sarana untuk meningkatkan mutu pendidikan, memenuhi harapan pelanggan dan perbaikan berkelanjutan. Fokus arah pelaksanaan Sistem Manajemen Mutu (SMM) ISO 9001:2008 di Madrasah Aliyah Negeri 3 Palembang adalah untuk mencapai kepuasan pelanggan customer satisfaction (siswa dan orang tua) melalui:1) peningkatan kualitas prestasi siswa, 2) pencegahan terjadinya penurunan kualitas prestasi siswa. Alasan penerapan ISO 9001:2008 di Madrasah Aliyah Negeri 3 Palembang adalah: 1) memastikan seluruh kegiatan lembaga dapat berjalan dengan baik dan terus meningkat secara berkesinambungan, 2) membuktikan kepada seluruh stakeholder bahwa lembaga bertanggung jawab untuk seluruh kegiatan peningkatan dan pemeliharaan mutu pendidikan.

Berdasarkan hasil observasi penulis di lapangan permasalahan dan kendala yang terjadi adalah siswa sering mengeluh tentang fasilitas di ruang kelas dan wc siswa. Masalahnya adalah menurut pendapat siswa bahwa fasilitas di ruang kelas kurang memadai disebabkan kipas angin yang mati dan proyektor yang rusak. Kemudian masalah di wc siswa yaitu pintunya yang rusak, lampu yang tidak menyala dan air di bak mandi yang kosong. Hal ini perlu diperhatikan oleh pihak Madrasah agar kebutuhan dan harapan siswa dapat terpenuhi. Madrasah Aliyah Negeri 3 Palembang perlu melakukan perbaikan berkelanjutan, yang dijalankan secara internal melalui penerapan Sistem Manajemen Mutu ISO 9001:2008 untuk mewujudkan visi dan misinya dalam memuaskan pelanggan yaitu siswa. Tujuan dari penerapan Sistem Manajemen Mutu ISO 9001:2008 di Madrasah Aliyah Negeri 3 Palembang adalah untuk memenuhi kebutuhan dan harapan siswa sebagai pelanggan eksternal.

Manfaat dari penerapan ISO 9001:2008 di Madrasah Aliyah Negeri 3 Palembang adalah untuk mengontrol kepuasan siswa melalui survei layanan madrasah yang terdapat di dalam penerapan ISO 9001:2008. Penelitian ini bertujuan untuk mendeskripsikan penerapan Sistem Manajemen Mutu (SMM) ISO 9001:2008 dengan menerapkan konsep plan, do, check, action (PDCA). Kemudian konsep itu direncanakan melalui prinsip manajemen 
mutu yaitu fokus pada pelanggan yaitu siswa. Kemudian menganalisis kendala-kendala dalam penerapan Sistem Manajemen Mutu (SMM) ISO 9001:2008 tersebut dan upaya untuk mengatasinya. Oleh sebab itu diperlukan proses pengumpulan data di lapangan memahami obyek yang berhubungan dengan cara yang ilmiah untuk memenuhi data penelitian.

\section{KAJIAN LITERATUR}

Kerangka teori terbagi dua yaitu penerapan Sistem Manajemen Mutu(SMM) ISO 9001:2008 di Madrasah Aliyah Negeri 3 Palembang dan menganalisis kendala di dalam penerapan ISO 9001:2008 tersebut. Adapun penerapan ISO 9001:2008 di Madrasah Aliyah Negeri 3 Palembang menggunakan konsep PDCA (plan, do, check, action). Dimana plan adalah fokus pada pelanggan yaitu siswa, kemudian do melalui pelaksanaan ISO 9001:2008 yaitu survei layanan madrasah. Check yaitu mengontrol keluhan siswa melalui angket kepuasan siswa, berdasarkan kinerja ketersediaan fasilitas di dalam pelaksanaan ISO 9001:2008 di Madrasah Aliyah Negeri 3 Palembang tersebut. Analisis kendala penerapan ISO 9001:2008 di Madrasah Aliyah Negeri 3 Palembang yaitu kendala fasilitas yang termasuk dalam Standar Nasional Pendidikan (SNP) yaitu Standar Sarana dan Prasarana. Analisis kendala Standar Sarana dan Prasarana ini adalah masalah fasilitas di ruang kelas dan jamban siswa untuk dilakukan tindakan perbaikan oleh pihak Madrasah. Action adalah bagaimana upaya pihak Madrasah untuk mengatasi masalah ruang kelas dan jamban siswa agar siswa merasa puas terhadap pelayanan yang diberikan sehingga proses belajar mengajar bisa berjalan dengan lancar.

Penerapan ISO 9001:2008 dilatarbelakangi oleh dua macam kondisi yaitu kondisi kontraktual dan kondisi non kontraktual (Pradana, 2003). Kondisi kontraktual, yaitu suatu kondisi dimana organisasi dituntut oleh persaingan, sedangkan kondisi non kontraktual adalah kondisi dimana penerapan ISO didasari oleh kepentingan organisasi itu sendiri dalam rangka mengembangkan kinerja internal organisasi itu sendiri. Dari teori diatas penulis menganalisis bahwa penerapan ISO 9001:2008 di Madrasah Aliyah Negeri 3 Palembang didasari oleh kepentingan organisasi untuk memuaskan pelanggannya yaitu siswa.

Pelanggan adalah pemangku kepentingan yang disebut stakeholders, adapun stakeholders yang dimaksud adalah siswa dan orang tua (Muhaimin, 2009:138). Pelanggan dalam lembaga pendidikan dibagi dalam dua kelompok yaitu pelanggan internal dan eksternal. Adapun pelanggan internal adalah pelanggan yang berada di dalam organisasi sekolah dan berperan sebagai pengelola sekolah. Pelanggan internal adalah kepala sekolah, staf, dan guru. Pelanggan ekternal adalah pelanggan yang berada diluar organisasi 
sekolah yang secara langsung atau tidak terkena pengaruh akan mutu layanan sekolah. Pelanggan ekternal dikelompokan menjadi pelanggan primer, sekunder, dan tersier.

Pelanggan eksternal terbagi tiga yaitu pelanggan primer, sekunder dan tersier. Pelanggan primer adalah siswa, pelanggan sekunder adalah orang tua siswa, dan pelanggan tersier adalah masyarakat. Penulis menganalisis menurut (Nasution, 1992:22) yaitu fokus pada pelanggan dalam manajemen mutu, baik pelanggan internal maupun eksternal kedua-duanya merupakan driver yang sangat penting. Pelanggan eksternal menentukan kualitas produk atau jasa yang disampaikan kepada mereka, sedangkan pelanggan internal berperan dalam menentukan kualitas tenaga kerja, dan lingkungan yang berhubungan dengan produk atau jasa tersebut.

Menurut (Suardi, 2001:145) prinsip fokus pada pelanggan ini diterapkan secara optimal maka akan mengarah pada menyelidiki harapan pelanggan, memahami harapan pelanggan, kemudian memuaskan pelanggan, dan mengambil tindakan atas hasil yang diperoleh. Hal ini mengarah kepada delapan prinsip manajemen mutu pada pendidikan yang salah satunya adalah fokus pada pelanggan.

\section{METODE PENELITIAN}

Sejalan dengan uraian tersebut, usaha penulis untuk mengungkapkan data dan memahami makna dibalik kenyataan yang ada dengan cara masuk pada sumber langsung pada obyek penelitian Madrasah Aliyah Negeri 3 Palembang melalui wawancara, dokumentasi dan observasi. Maka pendekatan yang digunakan adalah metode deskriptif dengan pendekatan kualitatif. Pendekatan kualitatif perlu dilakukan untuk menganalisis kendalakendala yang dihadapi manajemen sekolah dalam penerapan Sistem Manajemen Mutu ISO 9001:2008, di Madrasah Aliyah Negeri 3 Palembang, serta upaya untuk mengatasi kendala-kendala tersebut.

Metode penelitian kualitatif adalah metode penelitian yang digunakan untuk meneliti pada kondisi objektif yang alamiah, dimana peneliti sebagai instrumen kunci (Sugiyono 2009:9). Melalui penelitian kualitatif, permasalahan penelitian dapat diketahui secara mendalam dan jelas karena permasalahan diteliti secara mendalam sesuai dengan data yang semakin berkembang. Berdasarkan teori di atas, disimpulkan bahwa metode penelitian deskriptif kualitatif adalah suatu cara melakukan penelitian secara mendalam dengan melihat dan mencatat setiap gejala yang ada sesuai dengan kondisi yang sebenarnya di lapangan, kemudian dipaparkan secara terperinci sehingga diperoleh gambaran yang jelas tentang temuan penelitian. Oleh karena itu penulis mewawancarai siswa dan siswi Madrasah Aliyah Negeri 3 Palembang mengenai kendala fasilitas tersebut. 
Penulis menganalisis menururt teori (Lincoln dan Gube, 1985) mengatakan bahwa dalam penelitian kualitatif ini, peneliti berperan sebagai instrument utama. Sejalan dengan pendapat diatas, maka yang menjadi instrument utama adalah penulis sendiri yang terjun ke lapangan serta berusaha sendiri mengumpulkan informasi. Menurut (Sugiyono, 2008:401) dalam penelitian kualitatif teknik pengumpulan data yang utama adalah observasi, wawancara, dan dokumentasi. Berdasarkan teori diatas penulis mengumpulkan data melalui wawancara dengan siswa, studi dokumentasi, dan observasi dilapangan.

\section{HASIL DAN PEMBAHASAN}

Pada penelitian ini penulis hanya menganalisis pada satu prinsip saja, yaitu fokus pada pelanggan. Dalam penerapan ISO 9001:2008 di Madrasah Aliyah Negeri 3 Palembang pelanggan yang dimaksud adalah pelanggan eksternal yaitu siswa sebagai pelanggan primer. Landasan yang digunakan dalam pelaksanaan sistem manajemen mutu menurut (Listyo, 2009:69) adalah Plan-Do-Check-Action (PDCA). Penulis menganalisis landasan PDCA mengarah kepada prinsip manajemen mutu menururt (Mulyono, 2009) yaitu fokus pada pelanggan, kepemimpinan, pelibatan orang, pendekatan proses, pendekatan sistem pada manajemen, perbaikan berkelanjutan, pengambilan keputusan berdasarkan fakta, dan hubungan yang saling menguntungkan dengan pemasok. Dalam penelitian ini penulis menganalisis hanya pada prinsip fokus pada pelanggan yaitu siswa sebagai pelanggan primer.

Penulis melakukan wawancara kepada (Hairil, Wakil Manajemen Mutu MAN 3 Palembang, tanggal 2 Juli 2015) bahwa pelanggan di Madrasah Aliyah Negeri 3 ini adalah siswa, fokusnya kepada kepuasan mereka, karena mereka adalah pelanggan yang harus dipenuhi pelayanannya secara baik, dengan memberikan pelayanan sesuai dengan apa yang dibutuhkan siswa dan siswi tersebut dengan menggunakan implementasi bisnis proses. Implementasi bisnis proses ini adalah bagian dari penerapan ISO 9001:2008 yaitu survei layanan madrasah.

Data hasil dokumentasi (Dokumen Pelaksanaan Kegiatan Survei Layanan Madrasah MAN 3 Palembang tahun 2014) menerangkan implementasi bisnis proses yaitu kegiatan pengumpulan data tentang pelaksanaan proses pembelajaran yang dilaksanakan di Madrasah Aliyah Negeri 3 Palembang selama satu tahun terakhir oleh melalui pengisian angket yang telah disediakan dalam aplikasi komputer terkait dengan pelayanan prima yang dilaksanakan di Madrasah Aliyah Negeri 3 Palembang. Hal ini merupakan bagian dari penerapan Sistem Manajemen Mutu ISO 9001:2008 di Madrasah Aliyah Negeri 3 Palembang. Untuk mengetahui seberapa puas pelanggan terhadap layanan yang diberikan, Madrasah Aliyah 
Negeri 3 Palembang menggunakan survei layanan madrasah. Adapun materi survei dari kegiatan implementasi bisnis proses (survei layanan madrasah) tersebut adalah sebagai berikut:
a. Tingkat kinerja kebersihan berdasarkan persepsi pelanggan.
b. Tingkat kinerja penataan lingkungan madrasah berdasarkan persepsi pelanggan.
c. Tingkat kinerja akademik berdasarkan persepsi pelanggan.
d. Tingkat kinerja ketersediaan fasilitas berdasarkan persepsi pelanggan.
e. Tingkat kinerja layanan umum berdasarkan persepsi pelanggan.
f. Tingkat kinerja manajemen berdasarkan persepsi pelanggan.

Semua materi survei tersebut adalah survei kepuasan pelanggan yaitu siswa di Madrasah Aliyah Negeri 3 Palembang, tetapi hanya lima tingkat kinerja yang berhasil memenuhi harapan siswa yaitu kinerja kebersihan, penataan lingkungan, akademik, layanan umum, dan manajemen (Dokumen Survei Layanan Madrasah MAN 3 Palembang, 2014). Akan tetapi tingkat kinerja ketersediaan fasilitas belum berhasil memenuhi harapan pelanggan yaitu siswa (Dokumen Survei Layanan Madrasah ISO 9001:2008 bulan September 2014). Data dokumen ini diperkuat dengan hasil wawancara kepada beberapa siswa dan siswi di Madrasah Aliyah Negeri 3 Palembang. Penulis mewawancarai narasumber yaitu siswi Madrasah Aliyah Negeri 3 Palembang (wawancara dengan Desi Anggraini, 9 November 2015) bahwa ia belum puas dengan masalah ketersediaan fasilitas di ruang kelas dikarenakan diruang kelas fasilitas seperti kipas angin tidak hidup, dan proyektor yang rusak. Adapun kebersihan tersebut adalah kebersihan jamban siswa dan fasilitas di jamban siswa yaitu pintunya yang rusak dan lampunya yang mati.

Penulis mewawancarai narasumber berikutnya (wawancara dengan Ade Septiani Putri, 9 November 2015) bahwa fasilitas di ruang kelas yang kurang memadai, seperti proyektor yang mati dan kipas angin yang tidak hidup yang menyebabkan proses pembelajaran kurang menyenangkan. Dari hasil wawancara dengan beberapa siswa dan siswi tersebut penulis menganalisis kendala-kendala dalam penerapan SMM ISO 9001:2008 di Madrasah Aliyah Negeri 3 Palembang adalah masalah fasilitas di ruang kelas dan wc siswa. Adapun masalah di ruang kelas adalah proyektor yang mati dan kipas angin yang tidak hidup. Kemudian masalah di wc siswa adalah pintu wc yang rusak dan lampunya yang tidak hidup.

Oleh karena itu penulis menganalisis penerapan ISO 9001:2008 dalam membantu pihak Madrasah dalam memantau kendala-kendala yang terjadi di lapangan sebagai keluhan siswa dan siswi Madrasah Aliyah Negeri 3 74 
Palembang sebagai pelanggan. Hal ini juga didukung teori (Nasution 2001, hal.218) bahwa tujuan diterapkannya ISO 9001:2008 adalah untuk mencapai dan mempertahankan mutu produk atau jasa yang dihasilkan, sehingga secara berkesinambungan dapat memenuhi kebutuhan para pelanggan.

Berdasarkan hasil wawancara, dokumentasi, penulis di lapangan permasalahan dalam penelitian ini yaitu keluhan siswa terhadap fasilitas di ruang kelas dan wc. Pertama masalah fasilitas di ruang kelas yaitu proyektornya yang mati dan kipas angin yang tidak hidup yang mengakibatkan siswa merasa terganggu ketika proses kegiatan belajar mengajar. Kedua masalah fasilitas di wc siswa yaitu pintunya yang rusak dan lampunya yang tidak hidup, akibatnya siswa merasa terganggu ketika mau buang air besar atau kecil. Hal ini harus menjadi perhatian bagi pihak Madrasah untuk dilakukan upaya perbaikan dan pencegahan agar keberlangsungan proses belajar mengajar dapat berjalan dengan lancar.

Seringkali siswa merasa kepanasan dan kurang nyaman ketika proses belajar mengajar dikelas karena kipas angin yang tidak hidup, dan proyektor yang mati menyebabkan siswa kurang fokus terhadap mata pelajaran yang sedang dipelajari (wawancara dengan Ade Septiani, 9 November 2015). Masalah lain di wc siswa yaitu pintunya yang rusak dan lampunya yang mati, hal ini menyebabkan siswa kurang nyaman ketika akan buang air, apalagi sedang dalam proses pembelajaran di kelas. Terkadang air yang ada di bak mandi siswa itu sering kurang dan kosong (wawancara dengan Ade Septiani, 9 November 2015) sehingga membuat siswa merasa kurang nyaman ketika akan buang air.

Hal ini sudah seharusnya menjadi perhatian bagi pihak Madrasah untuk diambil tindakan perbaikan, hal ini sesuai dengan teori (Hoyle David, 2006:31) bahwa perbaikan berkelanjutan harus dijadikan sasaran dan tujuan organisasi sehingga dapat diketahui dan ditetapkan dan kemudian juga organisasi mampu memantau kinerja melalui sasaran mutu yang terukur dengan melakukan tindakan perbaikan dan pencegahan. Tindakan perbaikan ini sejalan dengan teori Zakarya (2009:.8) bahwa ISO 9001 lebih memfokuskan diri terhadap perbaikan, penekanan pada kepuasan pelanggan, dan analisa data untuk perbaikan.

Nasution (2001:218) juga mengemukakan tujuan utama ISO 9000 adalah organisasi dapat mencapai dan mempertahankan kualitas produk atau jasa yang dihasilkan sehingga dapat memenuhi kebutuhan dan harapan pelanggan. Akan tetapi masalah kendala fasilitas di ruang kelas dan wc siswa ini bukan termasuk ke standar sarana dan prasarana pendidikan. Standar sarana dan prasarana pendidikan (Peraturan Menteri Pendidikan Nasional No.24, Tahun 2007, Standar Sarana dan Prasarana Sekolah/Madrasah Pendidikan Umum). Prasarana Ruang kelas untuk SMA/MA menurut 
(Peraturan Menteri Pendidikan Nasional nomor 24 tahun 2007) terdiri dari perabot, media pendidikan, dan perlengkapan lain. Perabot tersebut terdiri dari kursi peserta didik, meja peserta didik, kursi guru, meja guru, lemari, dan papan panjang. Media pendidikan tersebut terdiri dari papan tulis disetiap ruang kelas. Perlengkapan lain tersebut terdiri dari tempat sampah, tempat cuci tangan, jam dinding, dan kotak kontak. Masalah di ruang kelas siswa yaitu kipas angin yang mati dan proyektor yang rusak, tidak termasuk ke dalam standar sarana dan prasarana pendidikan. Kipas angin dan proyektor hanya sebagai fasilitas tambahan saja. Kipas angin dan proyektor itu hanya kemauan siswa saja, bukan termasuk dalan standar sarana dan prasarana, sehingga dananya adalah dari siswa itu sendiri dan dana DIPA.

Prasarana jamban atau wc siswa untuk SMA/MA menurut (Peraturan Menteri Pendidikan Nasional nomor 24 tahun 2007) terdiri dari kloset jaongkok, tempat air, gayung, gantungan pakaian, tempat sampah. Air di dalam bak mandi, lampu wc, dan pintu merupakan sarana penunjang untuk jamban siswa, dan bukan termasuk standar sarana dan prasarana untuk jamban. Artinya standar sarana dan prasarana pendidikan untuk ruang kelas dan wc siswa telah mencapai dan melebihi standar yang telah ada, akan tetapi dibutuhkan sarana tambahan untuk mencapai apa yang diharapkan oleh siswa sebagai pelanggan primer. Akan tetapi pihak Madrasah tetap harus memenuhi keinginan siswa dan siswinya sebagai pelanggan yaitu dengan cara mengganti kipas angin yang rusak dengan ac dan memberikan kepada setiap guru mata pelajaran proyektor pengganti untuk mengajar di kelas. Kemudian masalah di wc atau jamban siswa upaya yang dilakukan pihak Madrasah untuk memperbaikinya ialah segera memperbaiki pintu wc yang lepas, dan mengganti lampu wc yang mati dengan yang baru.

Melalui penerapan ISO 9001:2008 kendala-kendala yang dihadapi siswa dan siswi Madrasah Aliyah Negeri 3 Palembang dapat segera diatasi. Adapun untuk memantau kendala yang dihadapi siswa dan siswi tersebut adalah melalui survei layanan madrasah yang terdapat dalam penerapan ISO 9001:2008 tersebut. Data hasil dokumentasi (Dokumen Survei Layanan Madrasah MAN 3 Palembang, 2014) menerangkan Implementasi bisnis proses yaitu kegiatan pengumpulan data tentang pelaksanaan proses pembelajaran yang dilaksanakan di Madrasah Aliyah Negeri 3 Palembang selama satu tahun terakhir oleh melalui pengisian angket yang telah disediakan dalam aplikasi komputer terkait dengan pelayanan prima yang dilaksanakan di Madrasah Aliyah Negeri 3 Palembang. Tujuannya adalah untuk mengetahui seberapa puas pelanggan terhadap layanan yang diberikan.

Madrasah Aliyah Negeri 3 Palembang menggunakan survei layanan madrasah atau implementasi bisnis proses untuk mengetahui harapan dan 
kebutuhan pelanggan. Penulis sependapat jika ingin mengetahui harapan dan kebutuhan pelanggan dilakukan survei pengumpulan data melalui angket. Hal ini sesuai dengan teori yang dikemukakan oleh (Suardi, 2001:145) yaitu apabila prinsip fokus pada pelanggan ini diterapkan secara optimal yang akan mengarah pada hal-hal berikut, (a) menyelidiki dan memahami kebutuhan dan harapan pelanggan, (b) memastikan bahwa sasaran organisasi berhubungan dengan kebutuhan dan harapan pelanggan, (c) mengkomunikasikan kebutuhan dan harapan pelanggan dengan organisasi secara keseluruhan.

Melalui survei layanan madrasah dapat diketahui tingkat pelayanan kepada siswa apakah memenuhi atau melebihi harapan siswa, atau tidak mencapai target yaitu siswa kurang merasa puas terhadap pelayanan yang diberikan oleh pihak Madrasah Aliyah Negeri 3 Palembang. Oleh sebab itu pihak sekolah harus konsisten dalam penerapan ISO 9001:2008 untuk mencapai target yang diharapkan, sehingga penerapan ISO 9001:2008 dapat dilaksanakan secara maksimal. Penulis menganalisis dalam implementasi ISO 9001:2008 ada lima komponen yang harus dilakukan yaitu:
a. kepuasan pelanggan (customer satisfaction),
b. perbaikan terus-menerus (continual improvement),
c. komitmen (commitment),
d. konsistensi (consistence) dan,
e. perawatan (care).

Landasan yang digunakan dalam pelaksanaan sistem manajemen mutu menurut (Listyo, 2009:69) adalah Plan-Do-Check-Action (PDCA). Adapun perencanaannya (plan) adalah kepuasan pelanggan yaitu siswa sebagai pelanggan primer, kemudian pelaksanaannya (do) adalah pada suvei kepuasan pelanggan, evaluasi (check) adalah pada kendala-kendala yang dihadapi siswa sebagai pelanggan yaitu ruang kelas dan wc, kemudian tindakan (action) adalah upaya untuk mengatasi kendala ruang kelas dan wc siswa tersebut. Konsep PDCA ini intinya adalah perbaikan terus-menerus (continual improvement) serta konsisten dalam pelaksanaan sistem manajemen mutu tersebut,sebab tanpa konsistensi dari pihak manajemen sekolah maka pelaksanaan ISO 9001:2008 di Madrasah Aliyah Negeri 3 Palembang tidak akan berjalan secara maksimal.

Seluruh pihak sekolah baik kepala sekolah, staf, dan guru harus memiliki komitmen terhadap mutu. Mutu adalah suatu kondisi dinamis yang berhubungan dengan produk, manusia, proses, jasa, lingkungan yang memenuhi atau melebihi harapan pelanggan. Untuk lebih jelasnya Husein Umar (2002) membagi mutu menjadi delapan dimensi. 
a. Performance (performa) yaitu menyangkut karakteristik operasi dasar.

b. Durability (ketahanan) yaitu jangka waktu ketahanan sebelum tiba saatnya diganti.

c. Serviceability yaitu kemudahan servis atau perbaikan ketika dibutuhkan.

d. Aesthetics (estetik) yaitu menyangkut tampilan seperti rasa, bunyi, bau.

e. Perceived quality yaitu kualitas yang diterima dan dirasakan oleh customer atau pelanggan.

f. Conformance yaitu kesesuaian kinerja dan mutu produk sesuai standar.

g. Reability (keandalan) yaitu kemungkinan produk untuk tidak berfungsi pada periode waktu tertentu.

h. Features (fitur) yaitu item-item ekstra yang ditambahkan pada fitur dasar.

Performance (performa) menyangkut karakteristik dasar dalam kepuasan siswa dan siswi di Madrasah Aliyah Negeri 3 Palembang adalah mengatasi kendala fasilitas di ruang kelas siswa, seperti kipas angin dan proyektor, bahwa siswa tidak hanya puas hanya dengan adanya bangku, meja dan papan tulis saja, akan tetapi butuh fitur (features) tambahan yaitu seperti kipas angin atau pendingin ac, serta mengganti proyektor yang rusak dengan yang baru. Kemudian pihak Madrasah harus memikirkan ketahanan (durability) jangka waktu sebelum tiba saatnya diganti kipas angin atau ac tersebut dengan yang baru, sehingga pihak Madrasah menggunakan kipas angin dan proyektor serta ac yang tahan lama.

Kemudian perawatan (care) yaitu semua pihak Madrasah Aliyah Negeri 3 Palembang baik kepala sekolah, staf, guru, harus menjaga kepuasan siswa dan siswinya karena penerapan ISO 9001:2008 itu fokus pada pelanggan yaitu siswa dan siswinya. Untuk lebih jelasnya penulis merangkum penerapan ISO 9001:2008 di Madrasah Aliyah Negeri 3 Palembang ke dalam sebuah tabel. Berikut ini tabel penerapan ISO 9001:2008 Madrasah Aliyah Negeri 3 Palembang.

Table 1. Peneraapan ISO 9001:2008 MAN 3 Palembang

\begin{tabular}{lrllll}
\hline Plan & & Do & Check & Action & \\
Focus & pada & Survey & Ditemukan & Tindakan & \\
pelanggan & di & layanan & ketidaksesuaian & koreksi & dan \\
MAN 3 & yaitu & madrasah & & pencegahan & \\
\hline
\end{tabular}


(Analisis Kendala-Kendala Dalam Penerapan SMM ISO 9001:2008 di Madrasah Aliyah Negeri 3 Palembang)

\begin{tabular}{|c|c|c|c|}
\hline $\begin{array}{l}\text { siswa (customer } \\
\text { satisfaction) }\end{array}$ & $\begin{array}{l}\text { (implementasi } \\
\text { bisnis proses) }\end{array}$ & & \\
\hline $\begin{array}{l}\text { Perbaikan } \\
\text { berkelanjutan } \\
\text { (continual } \\
\text { improvement) }\end{array}$ & $\begin{array}{l}\text { Audit mutu } \\
\text { internal }\end{array}$ & $\begin{array}{l}\text { Ditemukan } \\
\text { ketidaksesuaian }\end{array}$ & $\begin{array}{l}\text { Tindakan } \\
\text { perbaikan }\end{array}$ \\
\hline $\begin{array}{l}\text { Perbaikan } \\
\text { berkelanjutan } \\
\text { (continual } \\
\text { improvement) }\end{array}$ & $\begin{array}{l}\text { Rapat } \\
\text { tinjauan } \\
\text { manajemen }\end{array}$ & $\begin{array}{l}\text { Hasil temuan } \\
\text { ketidaksesuaian } \\
\text { audit mutu internal } \\
\text { (AMI) dan hasil } \\
\text { survey kepuasan } \\
\text { pelanggan } \\
\text { (implementasi bisnis } \\
\text { proses) }\end{array}$ & $\begin{array}{l}\text { Pra audit } \\
\text { eksternal (AME) } \\
\text { yaitu persiapan } \\
\text { sebelum } \\
\text { menghadapi } \\
\text { audit mutu } \\
\text { eksternal }\end{array}$ \\
\hline $\begin{array}{l}\text { Perbaikan } \\
\text { berkelanjutan } \\
\text { (continual } \\
\text { improvement) }\end{array}$ & $\begin{array}{l}\text { Audit mutu } \\
\text { eksternal } \\
\text { (AME) }\end{array}$ & $\begin{array}{l}\text { Hasil temuan } \\
\text { ketidaksesuaian }\end{array}$ & $\begin{array}{lr}\text { Apakah layak } \\
\text { atau } & \text { tidak } \\
\text { menyandang } & \\
\text { setifikat } & \text { ISO } \\
9001: 2008 & \end{array}$ \\
\hline
\end{tabular}

Berdasarkan tabel diatas bahwa ISO 9001:2008 merupakan Sistem Manajemen Mutu (SMM) yang mengarah kepada kepuasan pelanggan, perbaikan berkelanjutan, konsistensi, komitmen, dan perawatan. Fokus pada pelanggan adalah pada kebutuhan dan harapan siswa MAN 3 Palembang. Pihak Madrasah harus bertanggung jawab terhadap keluhan siswa dan berupaya untuk memenuhi harapan mereka, dan jika ada kendala harus segera diperbaiki karena, Sistem Manajemen Mutu adalah merupakan sekumpulan prosedur terdokumentasi dan praktek-praktek standar untuk manajemen sistem yang menjamin kesesuaian dari suatu proses dan produk (barang/jasa) terhadap kebutuhan atau persyaratan tertentu. Kebutuhan atau persyaratan itu ditentukan atau dispesifikasikan oleh pelanggan atau organisasi (Gaspersz Vincent, 2002:268).

Sistem Manajemen Mutu ISO 9001:2008 merupakan sistem yang harus dilaksanakan dengan sebaik-baiknya, secara konsisten, kemudian semua pihak Madrasah harus berkomitmen terhadap mutu, dengan merawat dan menjaga sistem manajemen mutu itu sendiri. Sehingga masalah atau kendala yang dihadapi dapat segera diatasi, contoh masalah siswa ketika proses belajar mengajar dikelas jika mengalami hambatan seperti fasilitas kipas angin yang rusak diganti dengan pendingin ruangan AC. Kemudian proyektor yang rusak diganti dengan yang baru, seperti contoh setiap guru yang akan mengajar, diberikan proyektor pengganti. Masalah lainnya yaitu pintu kamar 
mandi yang rusak dapat segera diperbaiki agar siswa dapat terpenuhi kebutuhannya.

Berdasarkan uraian di atas penulis menemukan tujuan utama dari Sistem Manajemen Mutu ISO 9001:2008 adalah organisasi sekolah atau madrasah dapat mencapai dan mempertahankan kualitas produk atau jasa yang dihasilkan sehingga dapat memenuhi kebutuhan dan harapan pelanggan (Nasution 2001:218). Apabila prinsip fokus pada pelanggan ini diterapkan secara optimal maka akan mengarah pada hal-hal berikut, (a) menyelidiki dan memahami kebutuhan dan harapan pelanggan, (b) memastikan bahwa sasaran organisasi berhubungan dengan kebutuhan dan harapan pelanggan, (c) mengkomunikasikan kebutuhan dan harapan pelanggan dengan organisasi secara keseluruhan (Suardi, 2001:145).

Oleh karena itu, setiap lembaga sekolah atau madrasah harus memperhatikan apa yang diharapkan dan dibutuhkan oleh pelanggannya yaitu siswa sebagai pelanggan primer. Selain itu pihak sekolah juga harus konsisten dalam melaksanakan sistem manajemen mutu tersebut dan berkomitment bahwa mutu sekolah adalah hal yang utama, dan selalu menjaga nama baik sekolah.

Penulis menganalisis dalam implementasi ISO 9001:2008 pada lembaga pendidikan khususnya sekolah ada lima komponen yang harus dilakukan yaitu:
a. kepuasan pelanggan (customer satisfaction),
b. perbaikan terus-menerus (continual improvement),
c. komitmen (commitment),
d. konsistensi (consistence) dan,
e. perawatan (care).

\section{KESIMPULAN DAN SARAN}

Penerapan Sistem Manajemen Mutu di suatu sekolah atau madrasah dapat mengontrol keluhan pelanggan primer yaitu siswa dan siswinya. Penerapan ISO 9001:2008 di Madrasah Aliyah Negeri 3 Palembang menyelidiki kebutuhan dan harapan siswa dan siswinya dengan melakukan survei layanan madrasah kepada semua siswa terhadap apa yang mereka rasakan. Menganalisis kendala-kendala yang dihadapi siswa, pihak madrasah berupaya untuk mengatasi keluhan siswa agar kebutuhan mereka bisa tercukupi. Apa-apa saja yang diharapkan siswa bisa tercapai. Melalui pelaksanaan survei layanan madrasah maka keluhan siswa bisa teratasi.

Kendala fasilitas di ruang kelas, seperti kipas angin yang rusak dan proyektor yang rusak dapat segera diperbaiki sehingga harapan siswa bisa terpenuhi. Kendala fasilitas di wc/ jamban siswa seperti lampu yang mati, pintu yang rusak dan air yang sering kosong dapat segera diperbaiki. Adapun 
upaya pihak madrasah untuk memperbaikinya yaitu mengganti kipas angin yang rusak dengan ac, dan memberikan kepada setiap guru proyektor pengganti. Upaya pihak madrasah mengatasi kendala fasilitas wc/jamban yaitu segera memperbaiki pintu wc yang rusak, dan mengganti lampu yang mati dengan yang baru, kemudian senantiasa mengontrol apakah air sudah terisi atau belum.

Yang terpenting pihak sekolah atau madrasah memiliki lima komponen dalam penerapan Sistem Manajemen Mutu ISO 9001:2008 di Madarsah Aliyah Negeri 3 palembang yaitu:

a. kepuasan pelanggan (customer satisfaction),

b. perbaikan terus-menerus (continual improvement),

c. komitmen (commitment),

d. konsistensi (consistence) dan,

e. perawatan (care).

\section{DAFTAR PUSTAKA}

Gaspersz, V. (2002). Total Quality Manajement. Jakarta: PT gramedia Pustaka Utama.

Hoyle, D. (2006). ISO 9000 Quality System Handbook. Great Britain.

Lincoln, Y. S, \& Gube. E. G. (1985). Naturalistic Inquiry. Beverly Hill: Sage Publication.

Listyo, S. P. (2009). Implementasi Sistem Manajemen Mutu ISO 9001:2008 di Perguruan Tinggi Guidelines IWA-2. Malang: UIN Malang Press.

Muhaimin, et. all. (2009). Manajemen Pendidikan-Aplikasinya dalam Rencana Pengembangan Sekolah/Madrasah. Jakarta: Kencana Prenada Media.

Mulyono. (2009). Manajemen Administrasi dan Organisasi Pendidikan. Jogjakarta: Ar-Ruzz Media.

Nasution, M.N. (2001). Manajemen Mutu Terpadu. Penerbit: Ghalia Indonesia. Nasution. (1992). Metode Research. Bandung: Jemmars.

Peraturan Menteri Pendidikan Nasional No.24. (2007). Standar Sarana dan Prasarana Sekolah/Madrasah Pendidikan Umum.

Pradana, A. (2003). Analisis Pengaruh Penerapan ISO 9000 Terhadap Kinerja Perusahaan dalam Kaitannya dengan Praktik Manajemen Mutu. Bandung: Tugas Akhir TMI - ITB.

Suardi, R. (2001). Sistem Manajemen Mutu ISO 9000: 2000 Penerapannya untuk Mencapai TQM. Jakarta: PPM.

Sugiyono. (2009). Metode Penelitian Kuantitatif Kualitatif dan $R \& D$. Bandung: Alfabeta.

Umar, H. (2002). Riset Pemasaran dan Perilaku Konsumen. Jakarta: Gramedia Pustaka Utama. 
Zakarya, R. (2009). Pelaksanaan Audit Informasi Dalam Penerapan Manual Mutu ISO 9001:2008, Lembaga Penelitian. Jakarta: UIN Jakarta. 